\title{
A review on convenience and pollution caused by baby diapers
}

\author{
S. Aishwariya ${ }^{1, *}$, P. Priyanka ${ }^{2}$
}

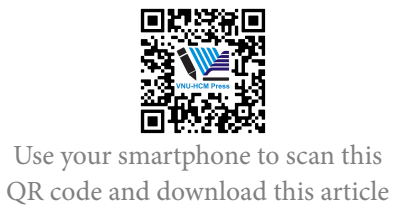

${ }^{1}$ INSPIRE fellow (DST) \& Assistant Professor, Department of Textiles and Clothing, Avinashilingam Institute for Home Science and Higher Education for Women, India

${ }^{2}$ Assistant Professor, Department of Costume Design and Fashion, Hindustan College of Arts and Science, India

\section{Correspondence}

S. Aishwariya, INSPIRE fellow (DST) \& Assistant Professor, Department of Textiles and Clothing, Avinashilingam Institute for Home Science and Higher Education for Women, India

Email: aishu55@gmail.com

\section{History}

- Received: 2020-05-23

- Accepted: 2020-08-18

- Published: 2020-09-19

DOI : 10.32508/stdj.v23i3.2399

\section{Check for updates}

\section{Copyright}

(c) VNU-HCM Press. This is an openaccess article distributed under the terms of the Creative Commons Attribution 4.0 International license.

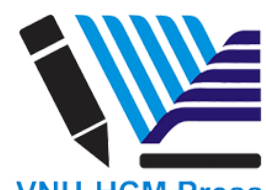

\begin{abstract}
The one-time use and throw material are both alluring and alarming. One such is a baby diaper that takes more than 400 years to degrade in a landfill. The industry is embracing nonwovens (pads, wipes, napkins) and single-use materials to cater to the huge demand from the consumer community. Hence, to combat this diaper pollution, awareness of both the sectors is important. The toxicity associated with a product loaded with chemicals and a conscious choice that is to be made between convenience and pollution is briefed here. The paper addresses the history, nature, market share of one-time disposals with a special focus on baby diapers. The pollution and challenges in recycling diapers along with sustainable brands and commercially successful companies making eco-friendly products are identified. The latest buzz, including biopolymers and circular economy, are also discussed to give a complete perspective on the topic.

Key words: disposals, degradable textiles, napkins, sustainable, diapers, eco-friendly, compostable
\end{abstract}

\section{INTRODUCTION}

A baby's birth changes one's life in all ways. In recent studies on parenting it clearly shows that parents are more concerned about offering the child a better standard of living than theirs. This naturally employs the use of materials that help in better health and hygiene. Diapers are identified as one such product that most of the children wear in the twentieth century. It has a few advantages like cost-effectiveness, easy to wear and dispose, saves time and water along with serving the main purpose, which is to keep the baby skin dry. It is reported that every five minutes, around 2,00,000 diapers ended up in landfills ${ }^{1}$. Even though the instructions on a diaper states the method to flush the poop, wash the diaper before disposing them on a bin, a consumer rarely does it in real-time. Additionally, it is studied that a child uses five to seven thousand diapers before moving to underclothes like panties and trousers.

\section{ONE TIME USE AND THROW DISPOSALS}

Globally, the purchasing power of an individual is increasing, which makes them invest in this category called one-time use and throw items ${ }^{2}$. These disposable products are designed to be used once or a few times and discarded away. The disposables used in houses are also increasing every year. Today, there are various options for one-time use and throw items like kitchen wipes, vessel washing scrub, shopping bags, tablecloths, towels, airline headrests, pillowcases, sorbents, sponges, and many more. Ironically, the disposals are alluring by giving a sense of sophistication and luxury to use a product and never see them again. Young members of the population are driving factors in the increase of market for disposals like facial wipes, cleansing wipes, and diapers. When they become adults, professionals the comfort of disposal gets on like a stigma. It is factual if we accept that today most of the households use kitchen wipes and not a washcloth in their cooking area, which was completely not seen in the last century. They have a huge market share in medical textiles to provide sanitation along with hygiene. Some of the commonly used disposable items are face mask, isolation gown, disposable trousers, coats, gloves, sleeve protector, bed sheets, napkins, wipes, and baby diapers. In a few cases, they are life-saving by preventing crosscontamination and prevent infections. Certain diapers have a very significant role, for instance, the adult diaper, which is of great utility for bedded patients, which helps in the sterility of the environment and keep the patient safe ${ }^{3}$.

The thoughtless use of such materials is a matter of concern. One such has been identified as the pollutant baby diaper (Figure 1). Generally, a disposal textile is embraced like a concept from the west and is celebrated much, with the least idea on the harmful nature it can cause from disposal into nature. The illeffects can be reversed nor compromised. Microplastic debris found in the ocean is believed to have come 
from the consumption of plastic-based materials like diapers. The list of disposals in the everyday life of a person goes endless, and only some are addressed to fit into the recycling stream. It is understandable that disposable material like a napkin, for example, helps women in many ways. But, women in both rural and urban sectors use sanitary napkins more than a permissible level. It is calculated that an average of 300 million users requires 15 billion pieces, which after use, end up in landfills. This milestone has a journey that actually began in a sustainable fashion, and its pattern changed later on. Findings suggest that babies wear a diaper for 3 to 6 hours approximately, 5 8 diapers on a day, and then disposed. Going against nature, these, failing to disintegrate, stay there for the next 100-500 years ${ }^{4,5}$.

\section{TIME TRAVEL TO PAST}

It is certain that the practice of using diapers was also part of modernization. However, each civilization had a tradition of its own in handling the situation. In the early stages, leaves of milkweed were used as wraps, hides of animals, and other creative materials from nature was used. Muslin, flannel, wool, and linen are the commonly used fabric called "napkins, pitchers, or clouts" cut in the shape of a square, rectangle, or triangle, fastened using with buttons, ties, or pins. The evidence portrays the use of sealskin, rabbit skin, grass, weeds, or moss around the baby's lower body and then placed in the cradleboard (Figure 2) ${ }^{6}$. When soiled, they were discarded to decompose in a natural way. Herbs like sphagnum moss, juniper bark, and cliffrose were commonly used for this purpose. In search of the diaper practices, it is found that the Chuckchi people of Eastern Russia carried their newborn in a fur bag with moss, as said earlier. When moss got wet, it was immediately changed. Countries like Europe, America, and India followed the cloth diaper method, in which the cotton fabric is folded in a breathable and easily removable fashion. Indians had a refined way of using the undyed old cotton textiles from their household to make cloth nappies for the newborn (Figure 3). The iconic muslin fabric (fine variety of cotton) is an entity of every household that is recycled in innumerable ways to make it an ideal material. Removal of wet cloth, washing, and sun-drying to kill germs was routine in the past. In China, the babies were placed in bags that contained sand, which can absorb the urine and keeps the baby dry. There were also various superstitious beliefs and myths with cloth nappies. In Indonesia, burning or burying diapers are believed to cause sickness and skin rashes in children. Hence, the disposal of the diapers into water bodies (canals, rivers, irrigation ditches) were followed $^{7}$. During 1880, mass production of cloth diapers, large safety pins, and the art of sanitization was popular in the community. Marion Donovan invented diaper cover made of nylon in 1940 and prefolds, flats during 1950. World war caused a shortage of cotton and also women to leave the house for work. The mothers during this time, we're looking for an alternative item for cloth nappy ${ }^{8}$.

This paves the way for accepting Disposable diapers, launched in 1948, as one-time use and throw nappies. It was designed with inner lining made of superabsorbent material that makes them work efficiently compared to cloth nappies. The diaper launch was not very acceptable in the initial stage, and it was made a success by the marketing strategy. The companies highlighted a few aspects like 'wetness' as a health hazard for baby, sleep-deprived new mothers, lack of time for laundry and drying in a busy lifestyle (Figure 4). Thus plastic based on time use and throw diapers were launched ${ }^{9,10}$.

\section{PAPER DIAPER (1956) BY P \& G}

Later, Mr. Vic Mills, Director of P\&G, observed the difficulty in diapering the newborn at his home and asked his team to develop a paper diaper. After a series of trial and error, in 1956, they launched the first commercial disposable diaper in Texas. It was difficult, expensive, and not appreciated well in the initial launch, but with constant efforts from the team to streamline production and cut down the cost, pampers evolved in 1959 and made a good sales record. At that point, $1 \%$ of the population accepted and used; today, $90 \%$ of the community is reported to use disposable diapers. Besides the advantages and comfort, this increase has been the cause for 18 billion diapers in the landfill every year ${ }^{11,12}$.

Diapers are predominantly made of plastic-based materials. The different parts are the diaper are discussed below (Figure 5)

- The top layer is a polymer-based nonwoven textile material. The fluid from this layer flows through the pulp layer to the core of the diaper to be stored, allowing the baby skin to be dry.

- The plastic outer layer with fastening that helps in holding the diaper onto the baby, unlike the conventional nappies where the knot manually may remove off, opening or falling of the nappy, which is overcome by the diapers. The elastic band in the waist and leg region helps in providing ventilation and ease in movement. Not being rigid like fabric, but draping on the baby 


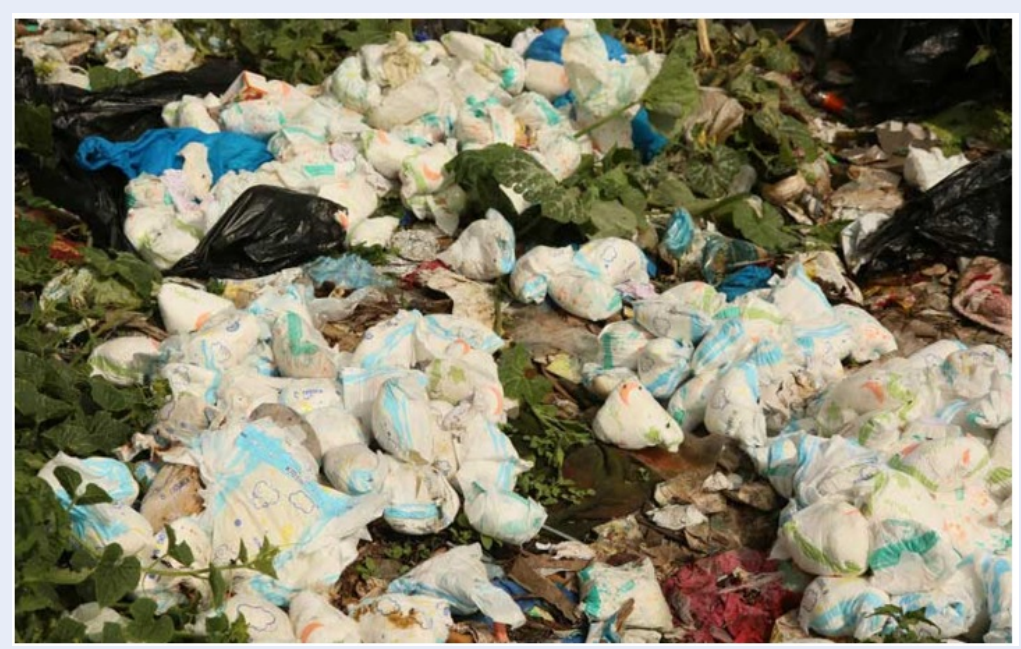

Figure 1: Landfill pollution by diapers - Statistically, it is reported that $\mathbf{3 0 0}$ million users need $\mathbf{1 5}$ billion pieces and each diaper takes $100-500$ years to decompose which is alarming when the population is ever increasing and land availability is going to be limited for dumping wastes. ${ }^{a}$

${ }^{a}$ Image courtesy: https://www.standardmedia.co.ke/article/2001356095/counties-agonise-over-piling-diaper-waste

body with the help of elastic that allows movement and avoids skin rashes.

- The cellulose fiber and super absorbent polymer (SAP) helps in absorbing the liquid. The cellulose is known for its natural absorbing property, like, for example, the popular cotton fabric made of cellulose. SAP, being man-made absorbent, has the amazing property of absorbing 500 times its own weight, offering a huge opportunity for frequent wetters.

- Leakage is prevented by a plastic bottom layer and by elastic barriers.

- Polymer-based resins are used in sticking the parts together in the making of the diaper.

- Overall, the Packing of a diaper is done using plastic (polyethylene) cover, and they are also given away in a plastic shopping bag.

Even an educated consumer fails to realize that making diapers involves cutting trees, making plastics, toxic chemicals, transportation, production waste that can pollute the air, water, and soil. Diapers are more of a biohazard to the child. The one time, use, and disposed of plastic bottles are most spoken, ignoring the diapers, napkins that are equally toxic and more complex to recycle. The basic ingredient in making polyethylene plastic, part of disposable textiles, is synthetic oil. Studies suggest that one disposable diaper consumes one cup of oil, quoting the high carbon footprint, claiming the production as nonecofriendly. This is not known to the majority of the consumer. A Baby's sensitive and thin skin layer can be exposed to toxic mineral oil along with more than 50 chemicals by wearing a diaper ${ }^{13}$.

\section{DECODING DIAPER}

One of the dangerous constituents in a disposable diaper is the presence of Sodium Polyacrylate in the core of a diaper to enhance the absorbency of body fluids. It is unacceptable to see them even in diapers labeled eco-friendly. They appear to be gelatinous crystals, shiny and very small, sometimes can be spotted on the baby during diaper changing. This special material in water has the ability to absorb 100 times its own weight. It is sometimes spotted in the baby genitals and can cause allergy, irritation, fever, infections, and vomiting. This was legally banned in 1985 to be used in tampons because of the proven cases of Toxic Shock Syndrome. On the rat study, the material has caused hemorrhage, cardiovascular failure, and even death ${ }^{14}$.

A reported case quotes a baby's death on the consumption of 5 grams of this material from the diaper. Tin found in diapers may be organotin. Dioxin is another chemical in the diaper, which is a byproduct of bleaching paper, and labeled to have cancer-linked chemicals by the Environmental Protection Agency. It has also been banned in many countries, for it can lead to various health ailments like genetic damage, defective birth, diseases in liver and immune disorder when conducted a trial study on rats, and, therefore 


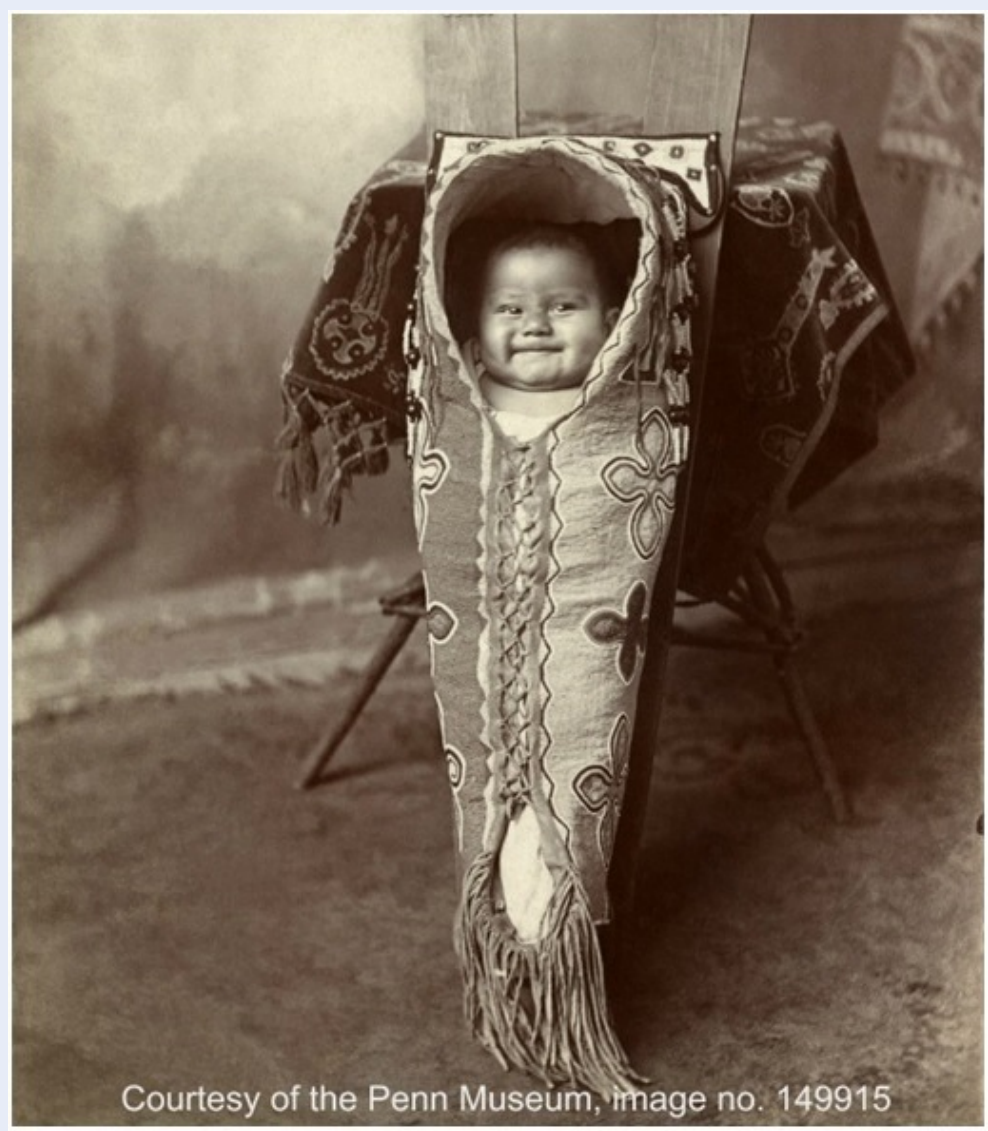

Figure 2: The image shows the new born kept in a box like cradleboard, which was either carried in front or in the back, while travelling with the child. Bio-based materials like sealskin,grass, weed, moss was placed around the baby bottom, that was thrown after being soiled, and replaced with a fresh set. ${ }^{a}$

${ }^{a}$ Image courtesy of www.zephyrhillblog.com

not recommended for humans. Phthalates, another plastic softening chemical, which is expelled from being used in teething ring due to it toxic nature, but unfortunately used in diapers. They are natural endocrine disruptors, which can imitate hormones and send false signals that may lead to health abnormalities in children. Tributyl Tin (TBT) and other heavy metals are also found in the diapers, which are highly toxic even in the minimum quantity. The side effects are a disruption in breathing disabilities, immune system, hormonal imbalance, and the ability to cause sterility in boys. Along with these, the dye used on the diaper is loaded with heavy metals that should be kept away from a baby and never to be worn as a second-skin-like diaper. Toluene acts as a depressant; Ethylbenzene is a proven carcinogen, Dipentene has been proved as a skin irritant, and Styrene is found to have caused various irritants in respiration. Along with these Methyl-cyclopentylamine,
m-Xylene, Trimethyl-cyclopentane, p-Anisaldehyde, Isopropyl benzene, Methyl cinnamate, Trichloroethylene, that are commonly found when testing a diaper. Overall, these can cause neurotoxicity, reproductive \& development toxicity, immunotoxicity, and endocrine disruption (hormonal damage) in babies $^{15-18}$

\section{WHY "NOT THE DIAPER"}

In India, 27 million children are born in a year, and the middle-class population is inclined to using more disposables. Central Pollution Control Board quotes the diapers are also not discarded properly, and burial or incineration is the common method adopted. Reports released by ECOTON, an environmental group in Indonesia, points out that diaper waste is higher than the plastic carry bags. The fish community in the Brantas river, unfortunately, has traces of plastic fibers to a great level that makes the situation alarm- 


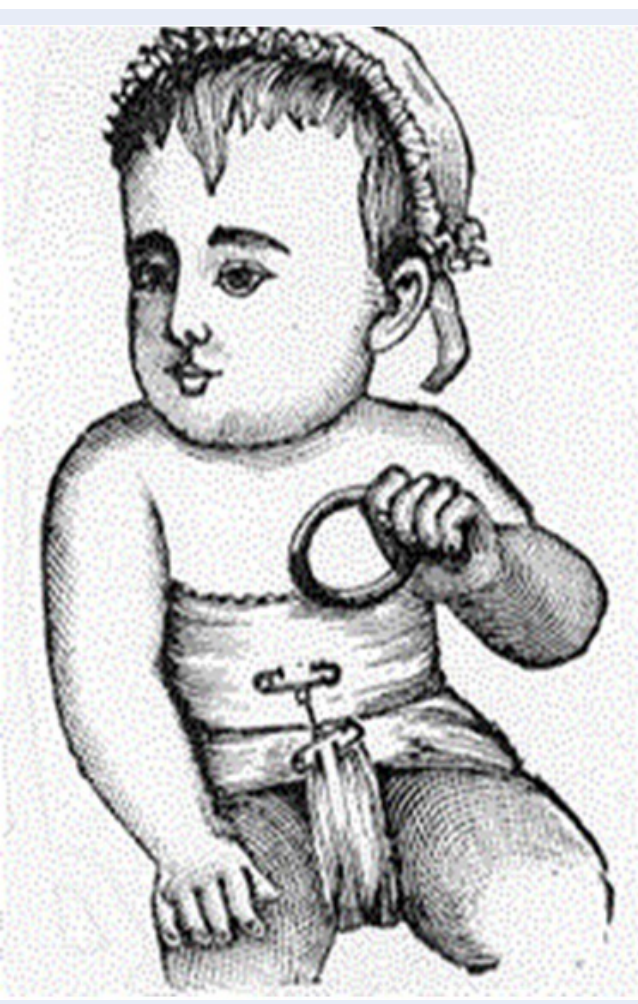

Figure 3: The illustration shows the practice in the olden days, where cotton fabric was wrapped around the waist and belly of the baby and secured with a pin. ${ }^{a}$

${ }^{a}$ Image courtesy of www.zephyrhillblog.com

ing and a global issue. The microplastic debris also from the diapers has resulted in coral mortality from disease and also affects the structure of the corals (Figure $6 \mathbf{a} \& \mathbf{b}$ ). It is found that the plastic debris abrades the coral tissues and even physical injury, creating a path for the entry of pathogens that will affect the immune system and result in dysfunction of wound-healing processes. It is a less known fact that more than 275 million people's life is dependable on coral for income, food, tourism, protection, and maintaining the balance in the ecosystem. In the U.S. and Europe, non-biodegradable items in landfills are creating a huge challenge, as diapers are getting into the sea in vast quantity, blocking the drainage, harming wildlife, and spreading diseases. They are a harmful item of marine litter, and scientific evidence is showing proof of disease on a coral reef (near the Maldives) caused by diapers. In South Africa, more than four billion plastic diapers are sold each year, and used diaper was just disposed of with no thought and dump bags, without eco-consciousness and ignorance on the future of disposed of the diaper ${ }^{19-22}$.

\section{CONSUMERS CHOICE BETWEEN CONVENIENCE AND POLLUTION}

A consumer has to understand that diapers are demons on land and soil. The composition of a diaper makes it extremely impossible for the microorganisms in the soil, air, water to attack them and decompose. The cycle of dispose-degrade-nourish, which is part of nature, is impossible. The result is soil leaching and expelling of plastics to underground water, air, soil, which eventually has proved to reach humans directly and indirectly. These diapers rank number three in the material's seen in the landfills, which are a huge task for any government to sort. Apart from the fact that diapers can cause various skin-based allergies, clogging of the toilets, and delay in potty training. The reports quote that 6000 diapers are used by a child, if one diaper is Rs. 10, still the amount spent on this is so huge and can be avoided and invested on better items. Besides, studies have predicted that it takes approximately 250 - 300 years for a diaper to degrade completely. To think of an alternative of waste like a diaper, which is holding, $50 \%$ of the household waste of a newborn, is significant. It does not stop there, and 


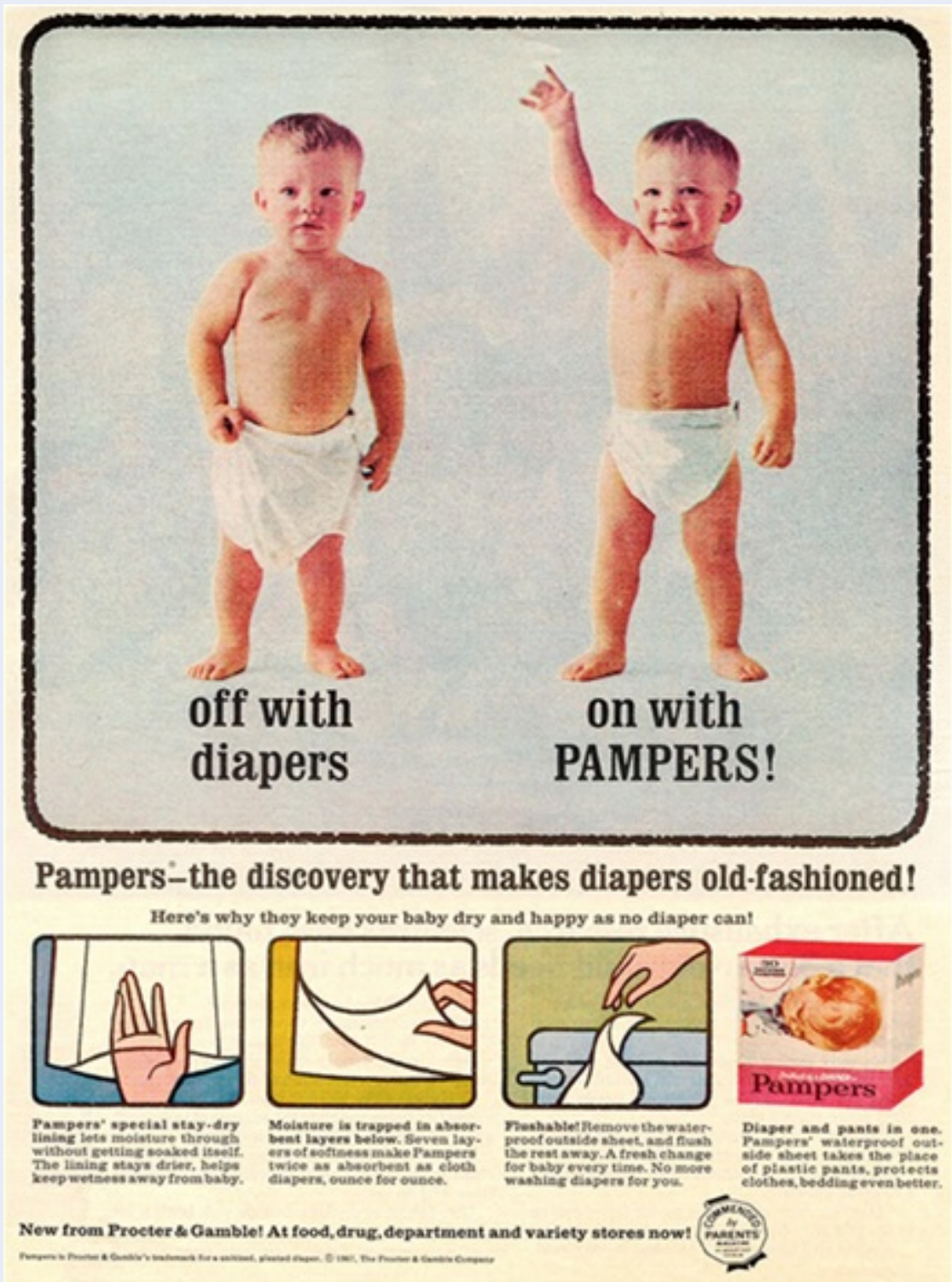

Figure 4: The image of a child with cloth nappy and a diaper was smartly used to communicate the message, that a child feels happy and confident with a diaper. ${ }^{a}$

${ }^{a}$ Image courtesy of www.zephyrhillblog.com

the devil lies in the detail. For example, in San Francisco, 70,000 babies are born in a year, and the average diapers used by them annually are close to 5000 diapers that will be in the landfill for 500 years.

Today there are various types of disposable diapers with different functionalities. As said earlier, a diaper is made of chemically processed wood pulp, sodium polyacrylate (super gel), polypropylene, and fragrances. Micro-fleece, micro-suede, and microfibers are other synthetics that are found inside the core of a diaper. The gel that is used is not very commendable and can be associated with toxic shock syndrome and skin irritations on the baby. Also, the use of bleaching agents to keep the padded white is extremely dangerous. The production of wood pulp is not sustainable due to its consumption of a huge amount of water and chemicals along with the generation of toxic effluent water at the end of the line. Thus, bamboo, wheat, and corn are experimented to be used instead of wood pulp to create a better product line. Today, some companies use organic cotton, hemp, and unbleached bamboo for their diaper making. In addi- 


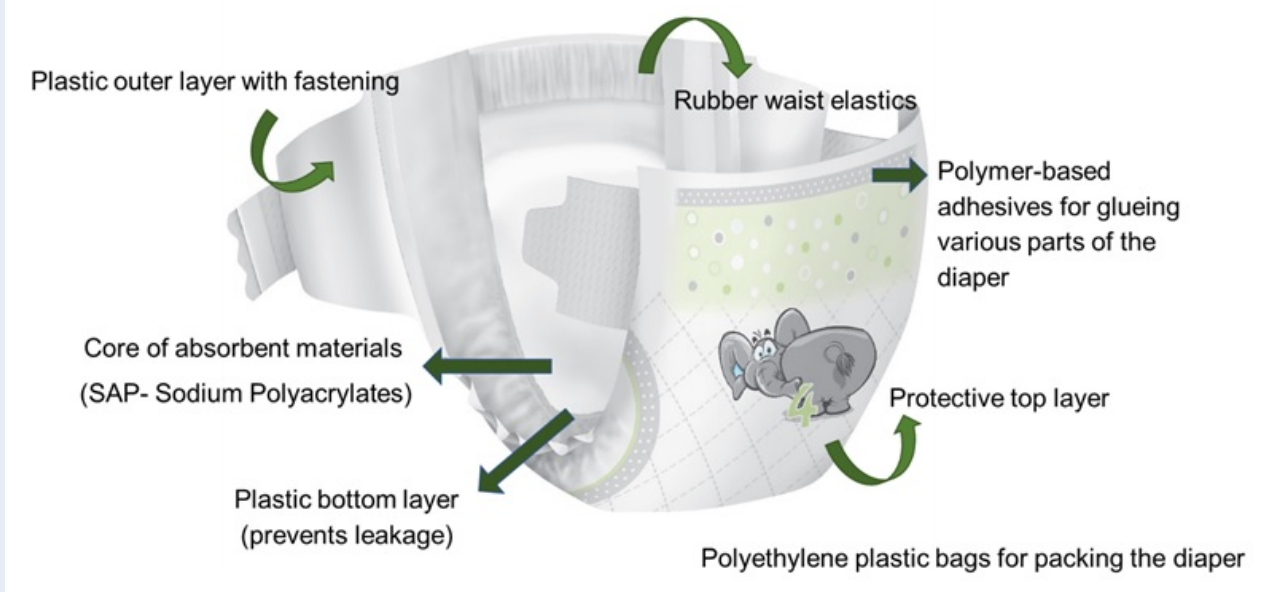

Figure 5: Parts of a Diaper - illustrating the different parts, its role and functionality along with different types of plastic like polymers in different parts/ layers of the diaper.
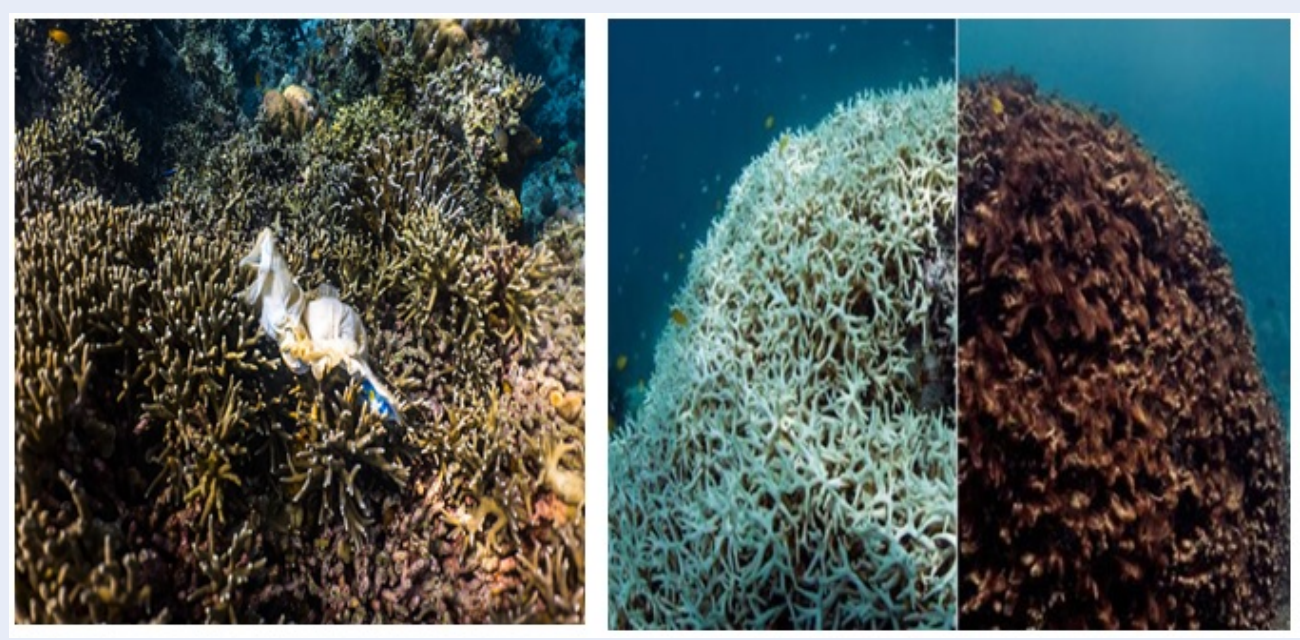

Figure 6: Diaper pollution affecting coral reefs in the ocean

a. A photograph of a diaper deposited on the coral

b. Comparing a healthy and infected coral - showcasing the impact of plastic debris on the immune system of corals, resulting in dysfunction of wound healing process and death. ${ }^{a}$

${ }^{a}$ Image courtesy: https://www.indiatoday.in/education-today/gk-current-affairs/story/plastic-waste-is-making-coral-reefs-sicksays-a-new-study-1155756-2018-01-28 
tion to the existing carbon footprint, the production is also adding on to the green-house gases that affect the ozone layer. If we get to know the environmental issues caused by these fibers, the conclusion could be suggesting to use only cloth diapers. But in the world of people buzzing with activity, water scarcity, electricity charges for laundering, it is a fact that consumers think and choose diapers to be better, which is not. The global warming caused by nappies has reduced by $14 \%$ with the weight reduction in the nappies. It is true that washing nappies in a fuller load, not washing above $60^{\circ} \mathrm{C}$, using energy-efficient appliances, less tumble drying, and reusing nappies for another baby rather than throwing in landfills. This can lower the global warming impact of $40 \%$. It is the research gap that is open for scholars and entrepreneurs to fit in the best sustainable solution to hitherto pollution ${ }^{23,24}$.

\section{DIAPER RECYCLING: CHALLENGES AND OPPORTUNITY}

The evidence portrays that 20 million tonnes of diapers reach landfills every year. The major drawback is the lack of process outlines from collecting, cleaning, breaking the diaper components, which is expensive and also challenging. This is the main reason for dooming all the efforts taken by companies across the globe until now. There is a support system needed from the consumers, investors, government, and allied companies to goad into action and shift the business from linear to a circular economy. In Mexico, $6.5 \%$ of landfill waste is reported to be a disposable diaper. A study has been done on bio-composting the collected, used baby diaper, and mixing them with garden waste. The result was a reduction of bio-mass by $87 \%$ along with good quality compost. The technique was suggested to be applied to small regions like daycare centers and kinder garden schools. These are companies like "Earth baby", who reach the doorsteps to collect the used diapers. The collected items are taken to the industry and composted into topsoil that is rich in nutrients. They term this technique as a compostable diaper service. The non-profit Diaper Evacuation Brigade in Java quotes the situations, and even after supplying boxes, 1.5 million diapers are thrown into the main river Branta ${ }^{25-28}$.

When we understand that water bodies connect the globe, everyone is going to be affected sooner or later. In an industrial scenario, the company which began making the diapers, $P \& \mathrm{G}$, proposed the idea to make high-value building blocks from recycling nappies, as they are made of high-quality plastics. P\&G sustainability agenda has been framed to select ten cities and recycle the Absorbent Hygiene Products (AHP) by 2030. Even though the companies are willing to adopt the recycling of diapers, they quote that's it is still uncertain if the consumers will be able to pay a higher premium price for it. Absolutely the fact in doing the right thing adheres to the company, the output from the diaper recycling company should also have a market. Perhaps a business plan that uses the community map and draws an idea to do so in a less populated country will be a good solution to prevent the diaper from being a pollutant. In a country like India, with a huge population, better alternatives are needed. This redirects us to take en route to sustainable solutions and install a circular economy in the production. Thus, it is evident to focus on traditional cost-effective practices and other sustainable alternatives ${ }^{29,30}$.

\section{Sustainable alternative - Cloth nappies}

Cloth diapers, diaper liners, and eco-friendly disposable diapers are alternatives to disposable diapers (Figure 8). In India, cloth nappies are the most traditional and popular. But due to the increase in the working women's ratio, many parents opt for onetime disposable diapers. Today, $90 \%$ of the population uses disposable diapers rather than cloth nappies. Cloth napkins are a traditional method for diapering the baby. It is made from cotton or linen and available as flat, shapes, fitted, shaped, or prefolded. The significance of the cloth diaper is the ability to be used multiple times, as also disinfected for hygiene. On an industrial scale, the cloth diapers laundry generates more wastewater, more energy, and increased consumption od renewable raw materials. This has been one of the suggested some options for consumers to shift to diapers; on deep analysis, the impact of using cloth nappy is less than a plastic diaper (Figure 7) ${ }^{31-36}$. The properties are compared in Table 1.

\section{Diversity in nappies}

Today $95 \%$ of the babies use disposable diapers rather than cloth nappies. The majority is the fact that the consumers lack the varieties available in using reuseable nappies that are made more efficient by using velcro, pins, or poppers. Some options (Figure 9) are discussed below

1. All-in-ones: Absorbent layer, waterproof cover, lining makes it an all in one nappy for the baby. These are shaped and fitted nappies which are hold on to the baby with a fastening like Velcro. There are a waterproof cover and no folding or pinning, which has been widely accepted for its versatility. They are simple to use but takes a long time to dry. All in two was 


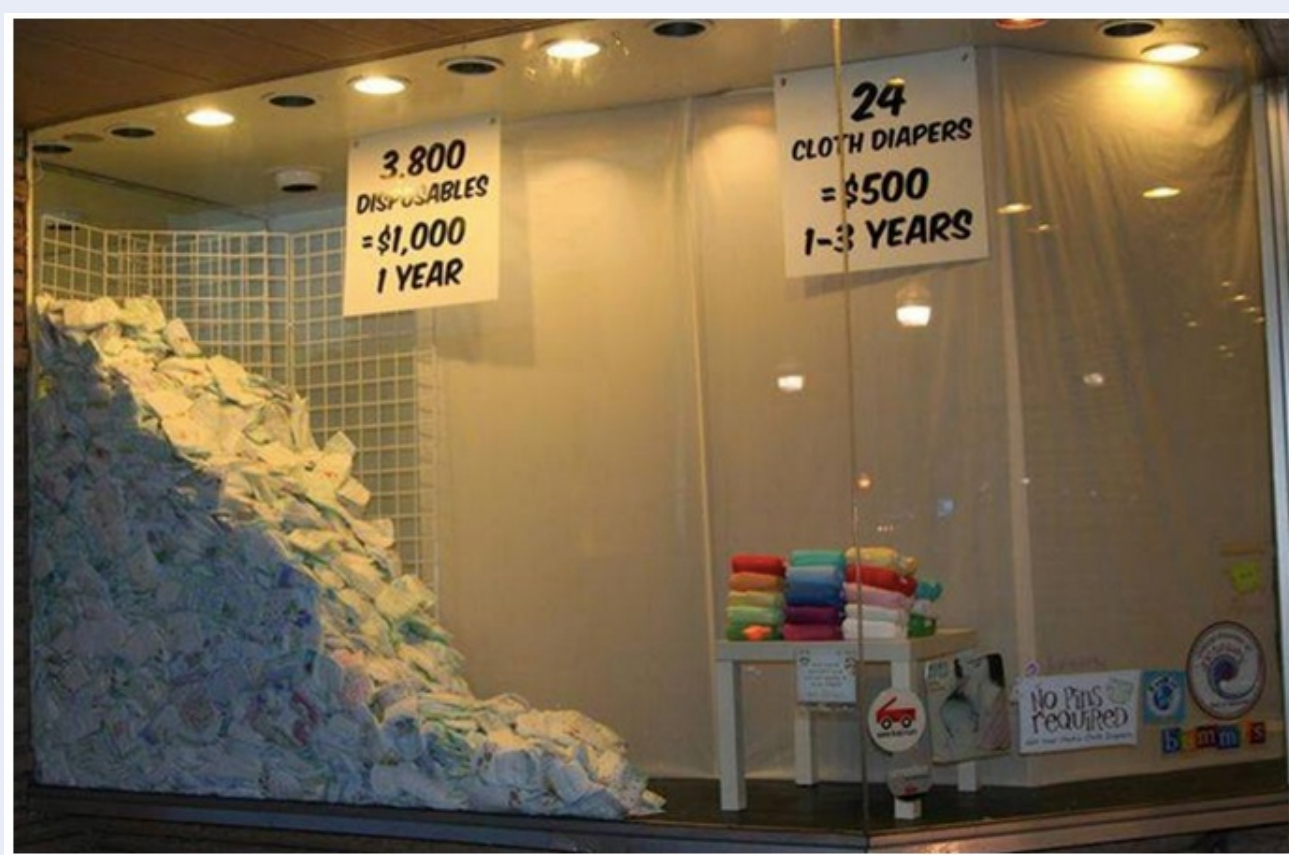

Figure 7: Window display comparing diaper and cloth napkins: Various eco-brands are promoting cloth nappies, and one such is this window display done by a brand, which gives a perception on the landfill pollution caused by diapers in one year, and comparitively, the quantity of cloth napkins needed for 3 years. ${ }^{a}$

${ }^{a}$ Image courtesy: https://www.smallfootprintfamily.com/dangers-of-disposable-diapers

another variation where the insert can be removed and dried, which overtook the demerit of high drying time.

2. Shaped nappies: It is similar to all-in-one nappies, with wraps, and must be bought separately with a waterproof cover. The nappies do not require folding or fasteners. They are available as shaped absorbent later and the waterproof outer cover or wrap. These are very good for night time, as they are usually bulkier and hold enough for a long time.

3. Prefolds are nappies that require folding (sometimes sewn), and along with a separate waterproof wrap and fasteners. Basically, these are flat cloth made of cotton (or recently bamboo) that are folded in a rectangular shape with layers that will enable better absorbency. These are simply called multilayer rectangle encompassing of three panels and usually made of terry cloth that has a pile structure, and that has maximum absorption. The fit is extremely good that makes it a choice for many mothers.

4. Pocket nappies are basically waterproof, disposable, and ensure a good fit. Just as the name describes, they have a pocket in front, back, or both for the placement of the insert or the absorbent layer. This is made of microfleece, suedecloth, or cotton, and the outer waterproof layer is made of PUL. They dry very quickly and are suitable for heavy wetting babies. Snaps or Velcro are commonly used as fasteners. They are available in one size that will fit for all in that age group, making it suitable for a longer period ${ }^{33-36}$ Cloth diapers will be expensive than a diaper, but on a longer run, the life cycle assessment will invoke the lesser carbon footprint using a cloth napkin. These are made using natural fibers, breathable materials like cotton, hemp, linen, bamboo, silk, flannel, wool, and hemp. It is inevitable that today the ill effects of one time disposals are spotted, and sustainable measures are taken. A Gujarat (India) based organization came up with a biodegradable sanitary napkin made of banana skin fiber. This process needed both sustainable \& naturally absorbent material, and banana fibers are efficient as pads. The fibrous middle layer of the banana stem is used as the perfect material for Saathi Pads, the brand. Processing is done to soften the harder part of the fiber, and the top and bottom layers are also made of plant-based material so that it degrades in a few months. Some of the sustainable brands are given in Table 2, and other brands include Honest company, Bamboo nature, Aden \& Anais, Pampers pure, $7^{\text {th }}$ generation, Babyganics, One that makes biodegradable diapers. 


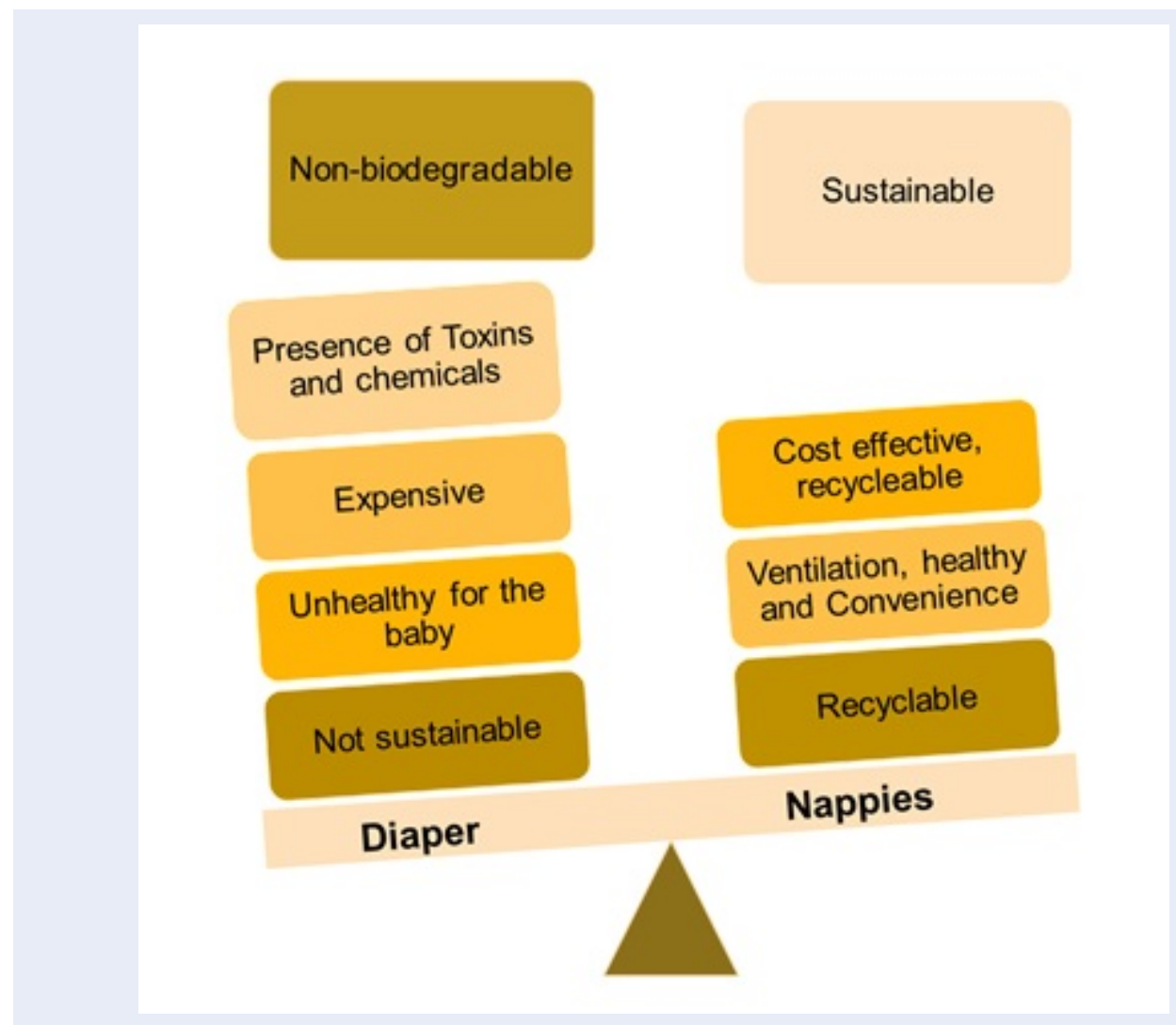

Figure 8: The merits of diaper comparing with a cloth nappy is quite high, however comparing the environmental aspect and 'sustainability', nappies stand out to be the better alternative, than the diapers.

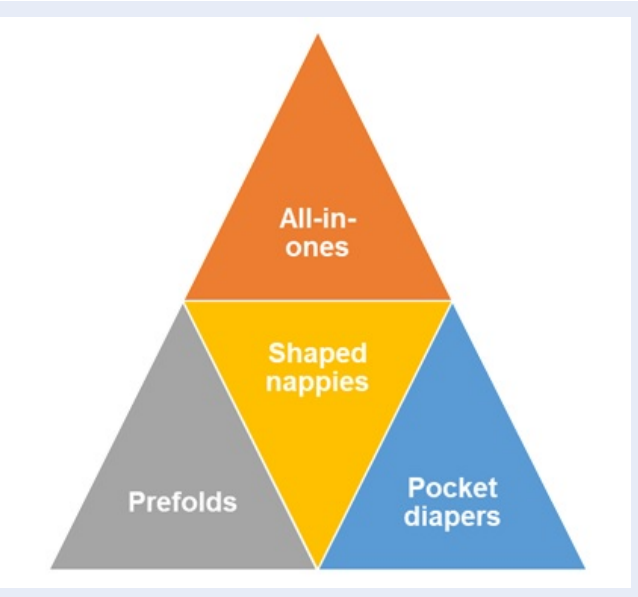

Figure 9: Most of the consumers across the world, lack the awareness of the options offered by a cloth nappy, which can be conveniently chosen based on preferences of the mother and child. 
Table 1: Comparing cloth nappy and disposable diaper

\begin{tabular}{|c|c|c|}
\hline Property & Cloth nappy & Disposable diaper \\
\hline Raw material & $\begin{array}{l}\text { Natural fibers and in some cases, nylon suede } \\
\text { polyester is used as non-absorbent material that } \\
\text { helps in the diaper to be dry }\end{array}$ & Polyethylene, polyurethane \\
\hline Merits & Ease in movement, ventilation, sustainable & Cheap to produce and easy to dispose \\
\hline Demerits & $\begin{array}{l}\text { The cost involved in washing, water and electricity } \\
\text { bills, baby-friendly detergent, drying rack, diaper } \\
\text { liner }\end{array}$ & $\begin{array}{l}\text { High temperature near the genital can lead to } \\
\text { reduced sperm count. The allergic reactions, } \\
\text { skin rashes, leading to toxicity, being expen- } \\
\text { sive, delay in potty training compared to cloth } \\
\text { nappies are some of the other hazards and away } \\
\text { from ecofriendliness }\end{array}$ \\
\hline Production & $\begin{array}{l}\text { Simple construction and less skill set are required. } \\
\text { In most cases construction is not needed and it is } \\
\text { just a square piece that's needed to make a nappy }\end{array}$ & $\begin{array}{l}\text { Various dye and fragrances are used to impart } \\
\text { visual beauty and appeal. Oil and petroleum } \\
\text { byproducts are used in production. Various } \\
\text { banned chemicals like Dioxin are used in the di- } \\
\text { aper. Asthma and skin irritation are commonly } \\
\text { reported cases resulting from the use of the di- } \\
\text { aper. }\end{array}$ \\
\hline Cost & $\begin{array}{l}\text { Once bought, they can be retained for a long time } \\
\text { and recycled into other homes when shared. }\end{array}$ & $\begin{array}{l}\text { Diapers are required for at least two years, and } \\
\text { the cost is five times higher than conventional } \\
\text { cloth nappy }\end{array}$ \\
\hline Convenience & $\begin{array}{l}\text { Complex folding procedures to change babies } \\
\text { These days come with snap buttons \& Velcro } \\
\text { strips. Leakproof bands that prevent and waste } \\
\text { from escaping around legs. Absorbent cloth di- } \\
\text { apers may have to change frequently. Traveling } \\
\text { with a cloth diaper and carrying soiled diapers is } \\
\text { seen as a trouble }\end{array}$ & $\begin{array}{l}\text { Easy to use, solving problems by simply throw- } \\
\text { ing them away when they are full and useful for } \\
\text { traveling. }\end{array}$ \\
\hline
\end{tabular}

Table 2: Eco-brand and the product specification

$\begin{array}{ll}\text { Eco-Brand } & \text { Product description } \\ \text { Poof Diapers } & \begin{array}{l}\text { Non-genetically-modified natural renewable materials are used in making the diaper. } \\ \text { Bamboo, organic cotton, and corn are used in the making. The added merit of these is } \\ \text { its ability to compost. The company also makes flushable plant-based wipes, free from } \\ \text { toxic chemical and fragrance. }\end{array} \\ & \begin{array}{l}\text { Certified by Standard } 100 \text { by OEKO-TEX these are compostable diapers. } 95 \% \text { of the raw } \\ \text { material disintegrates and gets flushed in toiletries }\end{array} \\ \text { Eco by Naty } & \begin{array}{l}\text { Certified by the FSC for babies with sensitive skin, they are compostable diapers. They have } \\ \text { a suggestion to remove their plastic-based components to be removed before composting. }\end{array} \\ \text { Bambo Nature } & \text { Collects diapers from household and conducts bio-digestion in Holland } \\ \text { Almere } & \begin{array}{l}\text { Diapers are recycled in Asia, Europe, and America } \\ \text { Knowaste LLC }\end{array} \\ \text { Bamboo Nature } & \text { color, skin-friendly, and bio-degradability have earned a position in the diaper industry. }\end{array}$


Diaper from Biobased materials from nature

These are materials that are made from natural sources like plant polyester, cellulose, protein, lignin, chitosan. These materials of organic origin are easily degradable, compostable, and preferred better to plastics. Hence, it is important to look at which bioplastic material is being used and how it degrades when disposed of. Thus, knowing the subtle differences is highly important to become a conscious consumer. Polymers are a huge threat to our environment, and studies have shown the replacement by bio-polymers for making the composites and nano-composites. Some studies show the use of the disposed of the diaper for the production of bio-hydrogen(bio-fuel). Bio-plastics is an upcoming area, and Europe has a strong market, and research on the development of compostable starch-based textile material to be used in diapers has experimented. There are patented novel polyesters that are proved to be degradable in waste composting scenarios. Such compostable diapers can be thrown at the landfills without fear. These will disintegrate into the soil after some time. Some studies have proved that the compost quality remains the same for diaper and municipal solid waste. it is interesting to know, the waste composted using diapers has similar properties to waste that does not have a diaper $^{37,38}$.

\section{Flushable diapers}

Enviro-guards is a popular brand that makes flushable diapers from microfibers. They are bio-degradable, flushable, ultra-thin pads with an acceptable shape and size are found to have good comfort properties as well. The pads after use, when flushed into the toilets, are disintegrated into smaller particles, and without clogging the pipes, they move forward to the water treatment plant. The cover stock is the first layer that is thin like a tissue paper, opens up and releases the contents inside, and later dissolved in the water completely. This is achieved by using patented microfibers that, when exposed to flushing agitation and cold water tends to breakdown into the smallest of particle size. Once it reaches the septic system, bacteria work on them and completes the action of degrading, as the microfibers are organically derived ${ }^{39-42}$.

\section{Circular economy}

Installation of bins in daycare centers and drug stores and parents using an app, can locate the nearby area will be an effective solution. A pilot study was done in Amsterdam, Netherlands, $70 \%$ of the parents have expressed the wish to recycle diapers. This suggests the need to bring up changes in the environment. A few initiatives were taken by the brands across the globe. P\&G started a diaper recycling factory in Italy. A group of researchers designed a diaper recycling machine that can handle 200 pounds of dirty diapers in an hour. Re-useable cloth diapers and redesigning the disposable nappy that can be compostable are the future-installing collecting points that can collect used nappy, which can be collected and recycled. The bacterial infection from the diapers can interpret in the composting chai; this makes the concept of biodegradable nappy each as a technology but difficult in a practical way. However, EDANA, the leading Global Association for Non-wovens, have mentioned that plastics from the diaper, will soon by advanced recycling technology to handle them ${ }^{43-47}$.

\section{CONCLUSION}

Plastic pollution and its awareness have created an alternative solution in various fields that uses one-time use and throw plastics, for example, the Food and Packaging industry. Manufacturers have shifted to the use of wood or paper-based materials to replace the plastics. In terms of these plastic-based diapers, many countries have faced a serious threat that disposables are banned in their locality. The places which are labeled to be eco-friendly and nature conscious, along with countries with limited land space like Australia, have taken the issue in a very real way and have reacted well. Diapers are a threat to the fact that it is loaded with a huge quantity of chemicals. This paper aims to bring awareness on this issue, which will pave the way for more researches on creating sustainable nappies for babies.

\section{AUTHORS' CONTRIBUTIONS}

The authors have efficiently collected the information and designed the flow of the article. Interpreting the collected litreature, supported with necessary illustration, drafted, revised the article for publication.

\section{CONFLICT OF INTEREST}

The authors have declared that no competing interests exist.

\section{ACKNOWLEDGEMENTS}

Nil 


\section{REFERENCES}

1. Aishwariya S. Waste Management Technologies in Textile Industry. Innov Ener Res. 2018;7(211):2576-1463.

2. Aishwariya S. Upcycling textile wastes into apparels and review on other sustainable solutions. Man-Made Textiles in India. 2018;46(10).

3. Kamat M, Malkani R. Disposable diapers: A hygienic alternative. The Indian Journal of Pediatrics. 2003;70(11):879881. PMID: 14703226. Available from: https://doi.org/10.1007/ BF02730591.

4. ;Available from: https://www.smallfootprintfamily.com/ dangers-of-disposable-diapers.

5. ;Available from: https://www.standardmedia.co.ke/article/ 2001356095/counties-agonise-over-piling-diaper-waste, Countiesagoniseoverpiling' diaper' waste, byJacintaMutura, January11th2020.

6. ;Available from: http://www.zephyrhillblog.com/2012/08/howgrandma-did-diapers/.

7. Krafchik B. History of diapers and diapering. International journal of dermatology. 2016;55:4-6. PMID: 27311778. Available from: https://doi.org/10.1111/ijd.13352.

8. ;Available from: http://diaperhero.com/splintered-crying/.

9. Saleem A. Are Disposable Diapers a Necessity? A Survey of Economically Deprived Mothers;

10. Steele RW. Diaper care for happier and healthier babies. 2014;PMID: 24961779. Available from: https://doi.org/10. 1177/0009922814540374.

11. Singh N, Purthi PK, Sachdev A, Gupta S. Disposable diapers: safe and effective. The Indian Journal of Pediatrics. 2003;70(9):721-722. PMID: 14620187. Available from: https: //doi.org/10.1007/BF02724314.

12. Prasad HRY, Srivastava P, Verma KK. Diaper dermatitis-an overview. The Indian Journal of Pediatrics. 2003;70(8):635637. PMID: 14510084 . Available from: https://doi.org/10.1007/ BF02724253.

13. ;Available from: https://www.smallfootprintfamily.com/ dangers-of-disposable-diapers.

14. ;Available from: https://science.sciencemag.org/content/359/ 6374/460.full.

15. ;Available from: https://www.parentcircle.com/article/7-factsabout-diapers-that-will-shock-you/.

16. ;Available from: https://www.gov.uk/government/ publications/an-updated-lifecycle-assessment-for-disposableand-reusable-nappies.

17. Umachitra G. Disposable baby diaper-a threat to the health and environment. Journal of Environmental Science \& Engineering. 2012;54(3):447-452.

18. ;Available from: https://www.huffingtonpost.in/entry/babydiapers-ocean-plastic_n_5cb77ea7e4b096f7d2db869b?ri18n= true.

19. Mugadza S. Options for the management and recycling of disposable diaper waste in Zimbabwe's urban areas. International Open and Distance Learning Journal. 2017;1(2).

20. Sultan MA, Hurriyati R, Aprianti V. When the Ecofeminists Decide Product to Use: A Simple Analysis on Cloth Diapers Users. In 3rd Global Conference On Business, Management, and Entrepreneurship (GCBME 2018). Atlantis Press . 2020;p. 11-15. Available from: https://doi.org/10.2991/aebmr.k.200131.004.

21. Prasad HRY, Srivastava P, Verma KK. Diapers and skin care: merits and demerits. The Indian Journal of Pediatrics. 2004;71(10):907-908. PMID: 15531833. Available from: https: //doi.org/10.1007/BF02830834.

22. ;Available from: https://www.thebetterindia.com/195846/ lifestyle-gujarat-eco-friendly-sanitary-pads-banana-fibreperiods-saathi-order-online/.

23. Freeman L. Disposable solution: P\&G gets ready to test compostable diapers. Advertising Age;61(43).

24. Sasikumar G, Senthil M, Visagavel K, Dheenathayalan T. Development of Bio-degradable baby diapers. International Journal of Research in Engineering and Technology.
2014;3(11):186-191. Available from: https://doi.org/10.15623/ ijret.2014.0323041.

25. ;Available from: https://www.youtube.com/results?search_ query=compostable+diapers.

26. ;Available from: https://www.reuters.com/article/us-italydiapers/waste-not-want-not-pg-venture-aims-to-squeezenew-life- out- of-italys-dirty-diapers-idUSKCN1MR26E.

27. ;Available from: https://www.greenmatters.com/p/are-diapersbiodegradable-compostable.

28. Best Natural Diaper test. 2019;Available from: https://www. youtube.com/watch?v=PFXNanWantw.

29. Zwane PE. Product development: reusable diaper. AUTEX Research Journal. 2010;10(1):31-34.

30. Lee TJ, Choi DC, et al. Studies on the Pulping Conditions of Separating Useful Components from Disposable Diaper Waste. Journal of Korea Technical Association of The Pulp and Paper Industry. 2015;47(2):1-8. Available from: https: //doi.org/10.7584/ktappi.2015.47.2.001.

31. Hale R. Newborn skincare and the modern nappy. 2007;Available from: https://doi.org/10.12968/bjom.2007.15.12.27797.

32. Lindahl $P$, Broman $G$, Robèrt KH. Material substitution and weight reduction as steps towards a sustainable disposable diaper. In Life Cycle Management. 2011;

33. ;Available from: https://easyscienceforkids.com/disposablediapers-pampers/.

34. ;Available from: https://parenting.firstcry.com/articles/clothdiapers-vs-disposable-diapers/?ref=interlink.

35. ;Available from: https://www.nappyheaven.co.nz/types-ofcloth-nappies.

36. ;Available from: https://www.madeformums.com/reviews/ nappies-what-types-are-there/.

37. ;Available from: https://www.which.co.uk/reviews/nappies/ article/how-to-buy- the-best-reusable-nappies.

38. ;Available from: https://www.nappyneedz.co.nz/cloth-nappytypes/.

39. Ferronato N, Nova PML, Torretta V. Assessment of Used Baby Diapers Composting in Bolivia. Sustainability. 2020;12(12):5055. Available from: https: //doi.org/10.3390/su12125055.

40. Khoo SC, Phang XY, et al. Recent technologies for treatment and recycling of used disposable baby diapers. Process Safety and Environmental Protection. 2019;123:116-129. Available from: https://doi.org/10.1016/j.psep.2018.12.016.

41. Espinosa-Valdemar RM, Sotelo-Navarro PX, Quecholac-Pina X, et al. Biological recycling of used baby diapers in a smallscale composting system. Resources, Conservation and Recycling. 2014;87:153-157. Available from: https://doi.org/10. 1016/j.resconrec.2014.03.015.

42. Lörcks J. Properties and applications of compostable starchbased plastic material. Polymer degradation and stability. 1998;59(1-3):245-249. Available from: https://doi.org/10. 1016/S0141-3910(97)00168-7.

43. Gallagher FG, Hamilton CJ, Hansen SM, Shin H, Tietz RF. Patent No. 5,171,309. Washington, DC: US Patent and Trademark Office. 1992;

44. Colón J, Mestre-Montserrat M, Puig-Ventosa I, Sánchez A. Performance of compostable baby used diapers in the composting process with the organic fraction of municipal solid waste. Waste management. 2013;33(5):1097-1103. PMID: 23465310. Available from: https://doi.org/10.1016/j.wasman.2013.01.018.

45. Colón J, Ruggieri L, Sánchez A, González A, Puig I. Possibilities of composting disposable diapers with municipal solid wastes. Waste Management \& Research. 2011;29(3):249259. PMID: 20406752. Available from: https://doi.org/10.1177/ $0734242 X 10364684$.

46. Joksimovic D, Khan A, Orr B. Inappropriate disposal of 'flushable' consumer products-reasons for concern. Performance Analysis Of Green Supply Chain Management Of Diaper Raw Materials. Dinasti International Journal of Digital Business Management. 2020;1(3):328-341. PMID: 32293593. Available from: https://doi.org/10.2166/wst.2020.087. 
47. Ng FSF, Muthu SS, Li Y, Hui PCL. A critical review on life cycle assessment studies of diapers. Critical reviews in environmen- tal science and technology. 2013;43(16):1795-1822. Available from: https://doi.org/10.1080/10643389.2012.671746. 